\title{
Analysis of the Breast Cancer Mortality Rate in Portugal Over a Decade: Spatiotemporal Clustering Analysis
}

\author{
Análise da Taxa de Mortalidade por Cancro da Mama em \\ Portugal ao Longo de uma Década: Análise de Clustering \\ Espácio-Temporal
}

Inês Afonso GOMES ${ }^{1,2}$, Carla NUNES $\square^{1,3}$

Acta Med Port 2020 May;33(5):305-310 - https://doi.org/10.20344/amp.11749

ABSTRACT

Introduction: Breast cancer is the first cause of cancer-related death in Portuguese women. This study aimed to characterize female breast cancer mortality in Portugal in the period between 2002 and 2013, with a special focus on spatiotemporal patterns.

Material and Methods: The breast cancer mortality rate was studied using descriptive analysis (unadjusted and age-adjusted), and spatiotemporal clustering analyses.

Results: In 2002 - 2013 the breast cancer mortality rate was 28.47/100 000 inhabitants and the age-adjusted mortality rate was 19.46/100 000 inhabitants. In this period the Lisbon region (urban), Alentejo and Algarve (rural) presented higher breast cancer mortality rate, but Madeira (urban), Lisbon and Algarve had higher age-adjusted mortality rate. In the spatiotemporal analysis, the overall mortality rate showed an increasing trend of $1.218 \%$ /year, without spatial variations. Also, different patterns were detected in the $<50$, $50-64$ and $\geq 65$ age-groups (+ 0.725\%, $-1.781 \%$ and $+0.896 \%$, respectively). One temporal $(2004-2006)$ and one spatiotemporal cluster (North coast) presented significantly lower mortality rate than expected for the period and/or area (26.2 and 16.1/100 000 inhabitants, respectively). Conversely, two spatiotemporal clusters, located in the city of Lisbon (2002 - 2007) and in the Centre region (2008 - 2013), presented significantly higher breast cancer mortality rate than expected (48.6 and 34.9/100 000 inhabitants, relative risk: 1.74 and 1.26 , respectively).

Discussion: The annual female crude and adjusted breast cancer mortality rate matched previous publications. However the annual increase detected in the unadjusted rate clashes with the published literature. Overall, the presence of spatiotemporal clusters supports the uneven distribution of the breast cancer mortality reported previously in the different Portuguese regions.

Conclusion: This study identified areas and trends of the female breast cancer mortality rate, showing high spatiotemporal variations that must support further detailed studies/interventions.

Keywords: Breast Neoplasms/mortality; Portugal; Space-Time Clustering; Spatio-Temporal Analysis

\section{RESUMO}

Introdução: O cancro da mama é a primeira causa de morte relacionada com cancro em mulheres portuguesas. Este estudo pretende caracterizar a mortalidade feminina por cancro da mama em Portugal no período de 2002 a 2013, com enfoque nos padrões espácio-temporais.

Material e Métodos: A taxa de mortalidade por cancro da mama foi estudada com recurso a análise descritiva (bruta e ajustada para a idade), e análise de clustering espácio-temporal.

Resultados: Em 2002 - 2013 a taxa de mortalidade por cancro da mama foi 28,47/100 000 habitantes e a taxa de mortalidade ajustada pela idade foi de 19,46/100 000 habitantes. Neste período a região de Lisboa (urbana), Alentejo e Algarve (rural) apresentaram taxas de mortalidade mais elevadas, mas após ajustamento pela idade a Madeira (urbana), Lisboa e Algarve demonstraram taxas de mortalidade superiores. Na análise espácio-temporal, a taxa de mortalidade geral apresentou um crescimento de 1,218\%/ano, sem variações espaciais. Adicionalmente, padrões diferentes foram detetados nos grupos de mulheres com < $50,50-64$ e $\geq 65$ anos (+ $0,725 \%,-1,781 \%$ e $+0,896 \%$, respetivamente). Um cluster temporal (2004 - 2006) e um espácio-temporal (costa Norte) apresentaram taxa de mortalidade significativamente mais baixas que o esperado para o período e/ou área (26,2 e16,1/100 000 habitantes, respetivamente). Por outro lado, dois clusters espácio-temporais, localizados na cidade de Lisboa (2002 - 2007) e na zona Centro (2008 - 2013), apresentaram taxas de mortalidade por cancro da mama superiores às expectáveis (48,6 e 34,9/100 000 habitantes, risco relativo: 1,74 e 1,26 , respetivamente).

Discussão: A taxa anual bruta e ajustada para a idade de mortalidade por cancro da mama aproximam-se das anteriormente publicadas. No entanto, o aumento anual nas taxas brutas contrasta com a literatura neste tópico. A presença de clusters espácio-temporais suporta a distribuição variável da taxa de mortalidade por cancro da mama nas diferentes regiões do país.

Conclusão: Este estudo identificou áreas e tendências na taxa de mortalidade feminina por cancro da mama, demonstrando variações espácio-temporais nesta taxa que suportam estudos e intervenções mais detalhadas nesta área.

Palavras-chave: Análise Espaço-Temporal; Conglomerados Espaço-Temporais; Neoplasias da Mama/mortalidade; Portugal

\section{INTRODUCTION}

Breast cancer $(\mathrm{BC})$ is the most frequent malignant disease and the most frequent cancer-related death cause in 30.1/100 000 inhabitants, ${ }^{3}$ age-adjusted MR [AMR] 18.4/100 000 inhabitants). ${ }^{2}$ In developed countries, the BC-MR has women worldwide ${ }^{1,2}$ and in Portugal ${ }^{3}$ (mortality rate [MR] displayed an evolution inverse to BC incidence, ${ }^{4-6}$ showing

1. Escola Nacional de Saúde Pública. Centro de Investigação em Saúde Pública. Universidade NOVA de Lisboa. Lisboa. Portugal.

2. Laboratórios Pfizer. Porto Salvo. Portugal.

3. Comprehensive Health Research Center. Universidade Nova de Lisboa. Lisboa. Portugal.

$\triangle$ Autor correspondente: Carla Nunes. cnunes@ensp.unl.pt

Recebido: 28 de dezembro de 2018 - Aceite: 04 de setembro de 2019 | Copyright $\odot$ Ordem dos Médicos 2020 
a sustained decline ${ }^{2,7,8}$ especially among the younger population, ${ }^{5}$ due to the scientific advances of diagnostic ${ }^{4,5,7}$ and therapeutic methods. ${ }^{4,5,8}$ The BC-MR in Europe and Portugal showed a decline since 1993 until 2010.7 Furthermore, between 2009 and 2011 the Portuguese female BC-AMR was among the lowest in the European Union, with an AMR for women $<65$ years in the second quintile and an AMR for $\geq 65$ years in the first quintile. ${ }^{9}$

Nowadays, BC mortality shows a high variability in different countries ${ }^{4,8}$ and regions ${ }^{4}$ and presents different patterns and trends according to the age of the patients studied. ${ }^{8,10}$ In 1994, the BC-MR was heterogeneously distributed throughout Portugal, with a higher rate being described in the south of the country (Lisbon and Alentejo regions) while northern Portugal presented the lowest MR. ${ }^{11}$ In the period 1990 - 2002 a reduction in the BC-AMR (European population) was described in all of the Portuguese districts except for four inland ones. Although the BC-AMR showed some decrease from 1990, the evolution of this rate was uneven when considering the different age-groups, with the oldest (65 - 74 years) showing a higher mortality than the younger women ( $35-44$ years, $45-54$ years and $55-64$ years).$^{12}$ Both BC mortality and AMR presented fluctuations in time and according to the different Portuguese regions under analysis, ${ }^{9,11,13-19}$ asymmetries that might be explained by unequal access to screening and treatment. ${ }^{11,12}$ This further supports the relevance of determining the MR patterns for the different regions and age-groups that comprise the Portuguese female population.

The study of the spatial distribution of diseases and their determinants, the ecological analysis of geographic correlations and the analysis of spatiotemporal clusters ${ }^{20,21}$ have been widely used in health studies. ${ }^{20}$ The latter identifies areas and years that present significant differences when compared with what is expected from the data of their surrounding $\mathrm{s}^{20,21}$ and the method of spatial variation in temporal trends detects temporal patterns within a certain geographical zone, allowing the identification of areas in which the evolution of diseases or/and their determinants does not follow the temporal global tendency. ${ }^{22}$ These methods were initially used by Kulldorff et al (among others) for the study of the geographical patterns of cancer ${ }^{23}$ and are fundamental in public health, both for the planning and evaluation of health interventions,,$^{20,21}$ often signalling the need to investigate certain geographical areas. ${ }^{24}$

Several spatiotemporal variation studies on BC mortality have been conducted in the United States of America ${ }^{25-28}$ and Japan.29-32 Additionally, three studies on BC mortality conducted in Spain detected a variation in this rate in different ages and counties through the use of spatial or spatiotemporal analyses. ${ }^{33-35}$ The study of the BC mortality trends according to the age of the patients can be extremely helpful in the development of age-specific health plans and could have major social and economic consequences. ${ }^{10}$ Furthermore, the analysis of spatiotemporal patterns can provide some guidance on the effectiveness of treatments over time and provide essential public health data that can help in setting health-care priorities by complementing incidence and survival analysis. ${ }^{36}$ To date, only limited data are available on the regional and temporal BC-MR evolution, and no evidence has been identified regarding the spatiotemporal variations of the mortality by this cancer in Portuguese women. Therefore, this study aims to characterize the BC mortality from 2002 to 2013 in Portuguese women, from a spatiotemporal perspective.

\section{MATERIAL AND METHODS \\ Data and sources}

A retrospective and observational study was carried out. The number of female deaths from BC and the median female population per year and per county in Portugal in the period 2002 to 2013 were obtained from Statistics Portugal (SP). Ethics committee approval and informed consent were not required, as the data were based on an official national surveillance system and had been previously anonymized.

\section{Methods}

As a first approach, a descriptive analysis of the number of deaths due to BC per area/year was performed. Furthermore, a general descriptive analysis was conducted on four not mutually exclusive age-groups ( $<50$ years, ${ }^{4,8,9,33} 50$ - 64 years, $\leq 64$ years [for comparability reasons], ${ }^{9,13-19} \geq$ 65 years). ${ }^{9,10,13-19}$ Annual MR was defined as the number of female BC deaths in a certain area and in a particular year divided by the median population (on the $30^{\text {th }}$ June) of female inhabitants in that same area and year. ${ }^{36}$ Three different space units were used in this study: Portuguese regions ( $n=7$ : Alentejo, Algarve, Centre, Lisbon, North, Azores and Madeira) and Portuguese counties ( $n=308$ or 278, for Portugal or mainland Portugal, respectively). The median population density in the period in analysis was calculated for each of the counties/regions and cut-off values of 150 and 300 inhabitants $/ \mathrm{km}^{2}$ were applied for the definition of rural, intermediate and urban area. ${ }^{37}$ The annual and global BC-MR for Portuguese women and for each region was calculated as an unadjusted rate, according to the defined age-groups and adjusted according to the European standard population (EU1976 ${ }^{38}$ ) by indirect adjustment, in order to allow external comparisons. ${ }^{38}$ The identification of temporal and spatiotemporal clusters plus the detection of spatial variations in temporal trends was conducted using the spatiotemporal scan statistics ${ }^{23}$ by means of a Poisson regression model (case counts) and circular windows with a maximum of $20 \%$ of the studied population. ${ }^{23}$ For this analysis, only the 278 counties in the Portuguese mainland were considered. The significance level was set at 0.05 and the MR was expressed per 100000 inhabitants. The data was analysed using the software IBM SPSS Statistics for Windows, Version 22.0 (IBM Corp. Released 2013. IBM SPSS Statistics for Windows, Version 22.0. Armonk, NY: IBM Corp.) and the results were mapped using the software QGISTM. 


\section{RESULTS}

\section{Analysis per region $(n=7)$}

The highest number of BC deaths in the period $2002-$ 2013 was observed in Lisbon (urban, 31.6\%), followed by North (intermediate, 26.3\%) and Centre (rural, 23.9\%) while the archipelagos (Azores and Madeira, rural and urban, respectively) presented the lowest number of $\mathrm{BC}$ deaths. Between 2002 and 2013, the highest BC-MR was reported in the Lisbon region (33.87/100 000 inhabitants), followed by Alentejo and Algarve (rural, 33.60 and 33.43/100 000 inhabitants, respectively). The regions that presented the lowest MR in this period were North, Azores and Centre (21.33, 25.44 and 30.59/100 000 inhabitants, respectively). When analysing the MR in the different age-groups, older women had a higher rate when compared with the younger agegroups studied (< 50 years: $4.32-7.02 / 100000$ inhabitants; $50-64$ years: $33.81-65.54 / 100000$ inhabitants; $\leq$ 64 years: $11.36-18.18 / 100000$ inhabitants; $\geq 65$ years: 66.65 - 104.45/100 000 inhabitants). Following adjustment by EU1976 (38), the Madeira region showed the highest AMR (26.92/100 000 inhabitants), followed by Lisbon and Algarve (23.16 and 23.12/100 000 inhabitants). The regions with the lowest AMR were North and Centre (15.91 and 18.85/100 000 inhabitants) (see Appendix 1: https://www. actamedicaportuguesa.com/revista/index.php/amp/article/ view/11749/Appendix_01.pdf).

\section{Analysis by county $(n=308)$}

The Portuguese counties presenting the highest BC-MR varied over time. In each of the years in analysis $17.5 \%$ $23.4 \%$ of the counties showed no deaths from BC, however, only six $(1.95 \%)$ counties presented no deaths by this cancer in the period $2002-2013$ (Table 1).

\section{Spatiotemporal analysis by counties $(\mathbf{n}=\mathbf{2 7 8})$}

In the period $2002-2013(n=17767)$, the annual female BC-MR was 28.4/100 000 inhabitants. The period 2004 - 2006 showed a significantly lower MR than the remaining years analysed (26.2/100 000 inhabitants, relative risk [RR] 0.90, $p=0.001$ ). The temporal analysis of the BC-MR showed a $1.218 \%$ increase per year in the studied period. Between 2002 and 2013 the BC-MRs in mainland Portugal were 5.9, 40.7, 14.1 and 84.6/100 000 inhabitants for the four age-groups in analysis, showing an annual variation of $+0.725 \%,-1.781 \%,-0.0907 \%$ and $+0.896 \%$, respectively. A significant difference in the BC-MR versus the remainder of the analysed period $(p=0.002)$ was detected in the 50 - 64 years group in $2002-2004$ (45.3/100 000 inhabitants, RR: 1.15$)$ and in the $\geq 65$ years group in 2002 - 2006 (78.7/100 000 inhabitants, RR: 0.91). No statistically significant spatial variations in temporal trends were detected in the total population or for any of the four age-groups studied. The spatiotemporal clusters identified are further described in Table 2 (Fig. 1).

Table 1 - Total and annual breast cancer number of deaths and mortality rate (per 100000 inhabitants) in the 308 counties of Portugal in the period of $2002-2013$

\begin{tabular}{|c|c|c|c|c|c|c|}
\hline Year & n (\%) & $\begin{array}{c}\text { Maximum rate } \\
\text { (county, number of deaths) }\end{array}$ & $\begin{array}{c}\text { Minimum rate } \\
\text { (number of counties; } \%)^{*}\end{array}$ & $\begin{array}{l}\text { Medium } \\
\text { rate }\end{array}$ & $\begin{array}{l}\text { Median } \\
\text { rate }\end{array}$ & $\begin{array}{l}\text { Standard } \\
\text { deviation }\end{array}$ \\
\hline 2002 & $\begin{array}{l}1,521 \\
(8.14)\end{array}$ & $\begin{array}{c}142.65 \\
\text { (Vila Velha de Rodão, rural inland, } \mathrm{n}=3 \text { ) }\end{array}$ & $0(n=71 ; 23.1 \%)$ & 26.80 & 22.94 & 24.00 \\
\hline 2003 & $\begin{array}{l}1,523 \\
(8.15)\end{array}$ & $\begin{array}{l}109.77 \\
\text { (Vila de Rei, rural inland, } \mathrm{n}=2 \text { ) }\end{array}$ & $0(n=66 ; 21.4 \%)$ & 27.43 & 23.87 & 23.95 \\
\hline 2004 & $\begin{array}{l}1,415 \\
(7.57)\end{array}$ & $\begin{array}{c}152.75 \\
\text { (Calheta, rural inland, } n=3 \text { ) }\end{array}$ & $0(n=67 ; 21.8 \%)$ & 25.98 & 23.01 & 24.21 \\
\hline 2005 & $\begin{array}{l}1,458 \\
(7.80)\end{array}$ & $\begin{array}{c}134.98 \\
(\text { Ferreira do Alentejo, rural inland, } n=6)\end{array}$ & $0(n=62 ; 20.1 \%)$ & 27.81 & 24.21 & 23.99 \\
\hline 2006 & $\begin{array}{l}1,433 \\
(7.67)\end{array}$ & $\begin{array}{c}105.49 \\
\text { (Castelo de Vide, rural inland, } n=2 \text { ) }\end{array}$ & $0(n=72 ; 23.4 \%)$ & 25.55 & 23.08 & 23.02 \\
\hline 2007 & $\begin{array}{l}1,553 \\
(8.31)\end{array}$ & $\begin{array}{c}285.23 \\
\text { (Calheta, rural inland, } \mathrm{n}=5 \text { ) }\end{array}$ & $0(n=60 ; 19.5 \%)$ & 29.35 & 25.48 & 27.50 \\
\hline 2008 & $\begin{array}{l}1,560 \\
(8.35)\end{array}$ & $\begin{array}{c}147.45 \\
(\text { Sabrosa, rural inland, } n=5)\end{array}$ & $0(n=72 ; 23.4 \%)$ & 28.31 & 25.42 & 24.75 \\
\hline 2009 & $\begin{array}{l}1,601 \\
(8.57)\end{array}$ & $\begin{array}{c}165.56 \\
(\text { Penamacor, rural inland, } n=5)\end{array}$ & $0(n=64 ; 20.8 \%)$ & 28.12 & 25.08 & 24.22 \\
\hline 2010 & $\begin{array}{l}1,644 \\
(8.80)\end{array}$ & $\begin{array}{c}115.47 \\
(\text { Mora, rural inland, } n=3)\end{array}$ & $0(n=60 ; 19.5 \%)$ & 29.46 & 26.15 & 23.99 \\
\hline 2011 & $\begin{array}{l}1,626 \\
(8.70)\end{array}$ & $\begin{array}{c}137.41 \\
\text { (Golegã, rural inland, } n=4)\end{array}$ & $0(n=66 ; 21.4 \%)$ & 28.26 & 25.98 & 23.88 \\
\hline 2012 & $\begin{array}{l}1,733 \\
(9.27)\end{array}$ & $\begin{array}{c}188.32 \\
\text { (Gavião, rural inland, } n=4 \text { ) }\end{array}$ & $0(n=65 ; 21.1 \%)$ & 29.51 & 28.50 & 24.03 \\
\hline 2013 & $\begin{array}{l}1,623 \\
(8.68)\end{array}$ & $\begin{array}{c}153.06 \\
\text { (Pedrógão Grande, rural inland, } n=3 \text { ) }\end{array}$ & $0(n=54 ; 17.5 \%)$ & 31.12 & 27.70 & 26.00 \\
\hline Total & $\begin{array}{c}18,690 \\
(100)\end{array}$ & $\begin{array}{c}59.39 \\
\text { (Penamacor, rural inland, } \mathrm{n}=22 \text { ) }\end{array}$ & $0(n=6 ; 1.95 \%)$ & 28.00 & 28.24 & 10.81 \\
\hline
\end{tabular}

* the names of the counties are not presented due to the high number of counties presenting the minimum mortality rate 
Table 2 - Breast cancer mortality spatiotemporal clusters on the 278 counties of mainland Portugal between 2002 and 2013 for all the female population and in the four age-groups considered

\begin{tabular}{|c|c|c|c|c|c|c|}
\hline Period & Age-group & $\begin{array}{l}\text { Cluster } \\
(p<0.05)\end{array}$ & $\begin{array}{l}\text { Number of deaths } \\
\text { (number of counties) }\end{array}$ & $\begin{array}{l}\text { Deaths observed } \\
\text { / expected }\end{array}$ & $\begin{array}{l}\text { Relative } \\
\text { risk }\end{array}$ & $\begin{array}{c}\text { Annual mortality } \\
\text { rate/100 } 000 \\
\text { inhabitants }\end{array}$ \\
\hline $2002-2007$ & \multirow{3}{*}{$\begin{array}{l}\text { Total } \\
\text { population }\end{array}$} & A: North Coast & $1001(45)$ & 0.57 & 0.54 & 16.1 \\
\hline $2002-2007$ & & B: Lisbon & $882(1)$ & 1.71 & 1.74 & 48.6 \\
\hline $2008-2013$ & & C: Centre & $1932(87)$ & 1.23 & 1.26 & 34.9 \\
\hline $2002-2007$ & $<50$ years & A: North Coast & $151(35)$ & 0.68 & 0.68 & 4.0 \\
\hline $2009-2013$ & \multirow{2}{*}{$50-64$ years } & A: North Coast & 297 (49) & 0.70 & 0.68 & 28.4 \\
\hline $2008-2010$ & & B: Lisbon & 324 (18) & 1.47 & 1.51 & 59.9 \\
\hline $2002-2007$ & \multirow{2}{*}{$\leq 64$ years } & A: North & 399 (35) & 0.62 & 0.60 & 8.7 \\
\hline $2002-2007$ & & B: Lisbon & $677(6)$ & 1.37 & 1.41 & 19.3 \\
\hline $2003-2008$ & \multirow{3}{*}{$\geq 65$ years } & A: North & 659 (81) & 0.63 & 0.61 & 53.5 \\
\hline $2005-2010$ & & B: Lisbon & $1020(10)$ & 1.35 & 1.39 & 114.2 \\
\hline 2007 - 2012 & & C: South & $989(46)$ & 1.20 & 1.22 & 101.3 \\
\hline
\end{tabular}

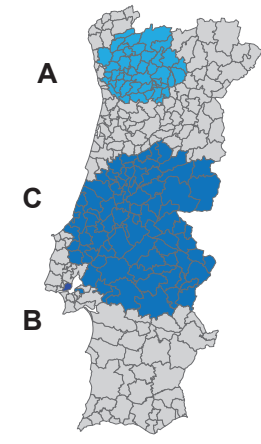

All

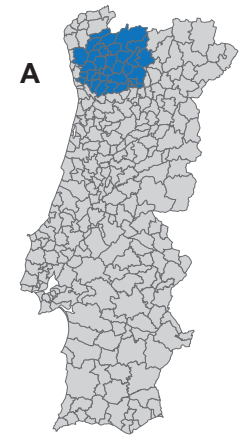

$<50$ years

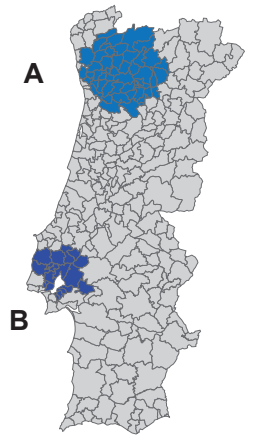

$50-64$ years

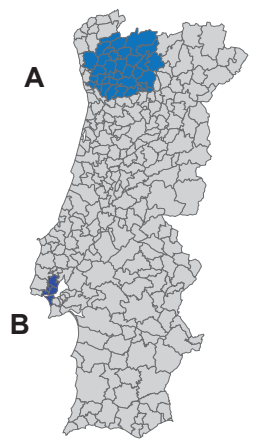

$\leq 64$ years

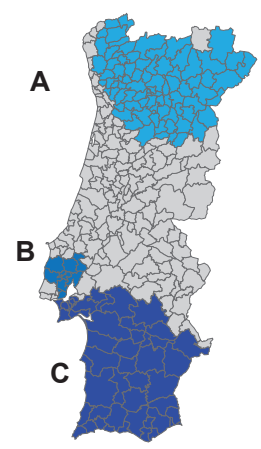

$\geq 65$ years

Figure 1 - Breast cancer mortality spatiotemporal clusters in Portugal between 2002 and 2013 globally and by age-groups

\section{DISCUSSION}

This study was the first spatiotemporal analysis of female BC mortality conducted in Portugal, contributing as a starting point for future studies in this area. In the studied period, the annual female BC-MR and age-adjusted BC-MR were 28.47 and 19.46/100 000 inhabitants, respectively, matching previous publications ${ }^{2,3,9,13,15-18}$ and placing Portugal above the mean BC-MR described for European women (15.2/100 000 inhabitants). ${ }^{5}$

As expected, large urban areas (Lisbon, Centre and North) reported a higher number of deaths from BC in 2002 - 2013 (high population density), however the highest BCMRs in this period were detected in the regions of Lisbon, Alentejo and Algarve (rural). A higher BC-MR has previously been described for the south of the country ${ }^{11}$ and this continuous trend might indicate the presence of environmental or genetic factors influencing mortality from this cancer in this rural area, or the inadequacy of the health services and public health measures in these zones when compared with the population's needs. The increased BC-MR described in Alentejo can be attributed to the presence of an aged population in this region (also previously reported), ${ }^{6}$ as the
AMR for this region was similar to the national rate. The high MR in the Lisbon region might be due to its urban setting, as suggested in a Spanish study, ${ }^{33}$ whereas the higher incidence of BC described in the Lisbon ${ }^{3,13,39}$ and Algarve ${ }^{13}$ regions might also be a reason for the concentration of $B C$ mortality in these areas. Additionally, there was virtually no organized screening actions for BC in the Lisbon area, which could also account for the increased mortality in this region. ${ }^{16}$ The fact that Madeira shows the highest BC-AMR might be a consequence of health determinants or health care differences in this area versus the rest of the country.

The annual $1.218 \%$ increase in the unadjusted BC-MR clashes with the published literature for this cancer in developed countries, ${ }^{2,4,5,7,8}$ a fact that can be explained by the non-age-adjustment of these data in the current study. In the period 2004 to 2006 , a significantly lower BC-MR was identified in the mainland Portugal. Additionally, three areas and periods were detected as showing a higher or lower MR than the rest of the country: two clusters with a superior MR located in the city of Lisbon (2002 - 2007, urban, $R R: 1.74)$ and in the Centre (2008 - 2013, rural, RR: 1.26), plus a cluster in the North that presented an MR below the 
expected for the area and period (2002 - 2007, intermediate, RR: 0.54$)$. These data support the uneven distribution of the BC mortality reported previously in the different Portuguese regions $\mathrm{s}^{6,9,11,13-19}$ when considering spatial and temporal variations.

When analysing the data according to the age-groups, the MR was lower in the younger women when compared with the elderly group. Both the older ( $\geq 65$ years) and the younger women $(<50$ years) showed an increasing trend in the MR $(+0.896 \%$ and $+0.725 \% /$ year, respectively) while the middle-aged group ( $50-64$ years) and the $\leq 64$ years had a decreasing tendency in the BC mortality in this analysis $(-1.781 \%$ and $-0.0907 \% / y e a r)$. The different patterns according to the patients' age could be explained by mammography screening and treatment advances, thus reducing the MR in young and middle-aged women, 8,10 and the stabilization of the MR in women $>65$ years could be attributed to the higher survival in younger age-groups, ${ }^{10,36}$ which leads to an accumulation of $\mathrm{BC}$ cases in the older agegroups $^{10}$ (delaying mortality from $\mathrm{BC}$ ) ${ }^{36}$ or to the reduced adherence to treatment guidelines in older women. ${ }^{8,10}$

The analysis of the BC-MR not considering different time periods since diagnosis, stage at diagnosis and exposure to different treatments might be a limitation of this study and a possible explanatory factor for the variability detected in certain counties/regions in the $2002-2013$ period. ${ }^{36}$ Therefore, future studies should include additional incidence and survival analyses. ${ }^{36}$ Additionally, the spatial differences detected in this health outcome could be attributed to various factors which were not considered in this analysis, such as socio-economic asymmetries, ${ }^{11,33}$ social factors, ${ }^{24}$ such as the percentage of elderly inhabitants, ${ }^{33}$ education or lifestyle factors, ${ }^{33}$ occupational/environmental exposure to pollutants, ${ }^{24}$ rurality, ${ }^{25,33}$ parity, race, ${ }^{25}$ local/regional screening programs, ${ }^{12}$ access to health care ${ }^{11,12}$ and information ${ }^{11}$ or heterogeneous distribution of $\mathrm{BC}$ cases $^{34,39}$ and risk factors ${ }^{24,34}$ in the country.

High BC-MR clusters can highlight the priority areas for public health action. The Lisbon region was pinpointed for all the female population, for middle-aged, $\leq 64$ years and for women $\geq 65$. Additionally, the south of the country showed

\section{REFERENCES}

1. International Agency for Research on Cancer - World Health Organization. GLOBOCAN 2012: Estimated cancer incidence, mortality and prevalence worldwide in 2012. [accessed 2016 May 28]. Available from: http://globocan.iarc.fr/Pages/fact_sheets_cancer.aspx.

2. Ferlay J, Steliarova-Foucher E, Lortet-Tieulent J, Rosso S, Coebergh JW, Comber $\mathrm{H}$, et al. Cancer incidence and mortality patterns in Europe: estimates for 40 countries in 2012. Eur J Cancer. 2013;49:1374- 403.

3. Registo Oncológico Regional do Norte. Registo Oncológico Nacional 2010. Instituto Português de Oncologia do Porto Professor Francisco Gentil EPE, editor. Porto; 2016. [accessed 2017 Jan 20]. Available from: http://www.roreno.com.pt/images/stories/pdfs/ro_nacional_2010.pdf.

4. Bray F, McCarron P, Parkin DM. The changing global patterns of female breast cancer incidence and mortality. Breast Cancer Res. 2004;6:22939.

5. Senkus E, Kyriakides S, Ohno S, Penault-Llorca F, Poortmans P, Rutgers E, et al. Primary breast cancer: ESMO Clinical Practice - Guidelines for diagnosis, treatment and follow-up. Ann Oncol. 2015;26:v8-30.

6. André MR, Amaral S, Mayer A, Miranda A. Breast cancer patients an increased $\mathrm{BC}$ mortality risk in women $\geq 65$ years, the age-group which represents the majority of $B C$ deaths in Portugal. The public health strategies and the health determinants that might explain these findings should be reassessed in order to improve these health outcomes. The North region was identified as the area with the lowest MR, prompting further analysis of local strategies and on the protective factors for BC mortality which could potentially be adopted in the critical areas identified in this study.

\section{CONCLUSION}

Although $\mathrm{BC}$ has been showing a decreased MR worldwide $^{4,5,8}$ it still has a high impact in terms of mortality in Portugal, corresponding to the first cause of death by malignant diseases in women. ${ }^{3}$ In this study, the areas with the lowest and highest female BC-MR were identified. This analysis showed that the BC-MR in Portugal was not homogeneous in the three dimensions investigated (time, geographic area and age at death). It is crucial to investigate these factors further in the identified clusters in order to tailor-design future $\mathrm{BC}$ public health strategies for the different Portuguese regions and populations.

\section{PROTECTION OF HUMANS AND ANIMALS}

The authors declare that the procedures were followed according to the regulations established by the Clinical Research and Ethics Committee and to the Helsinki Declaration of the World Medical Association.

\section{DATA CONFIDENTIALITY}

The authors declare having followed the protocols in use at their working center regarding patients' data publication.

\section{CONFLICTS OF INTEREST}

The authors report no conflicts of interest.

\section{FUNDING SOURCES}

This research received no specific grant from any funding agency in the public, commercial, or not-for-profit sectors.

survival and associated factors: reported outcomes from the Southern Cancer Registry in Portugal. Acta Med Port. 2014;27:325-30.

7. Amaro J, Severo M, Vilela S, Fonseca S, Fontes F, Vecchia C La, et al. Patterns of breast cancer mortality trends in Europe. Breast. 2013;22:244-53.

8. Autier P, Boniol M, LaVecchia C, Vatten L, Gavin A, Héry C, et al. Disparities in breast cancer mortality trends between 30 European countries: retrospective trend analysis of WHO mortality database. BMJ. 2010;341:c3620.

9. Direção-Geral da Saúde. Portugal: Doenças Oncológicas em números - 2014: Programa Nacional para as Doenças Oncológicas. Lisboa; 2014. [accessed 2016 Nov 5]. Available from: https://www.dgs.pt/ estatisticas-de-saude/estatisticas-de-saude/publicacoes/portugaldoencas-oncologicas-em-numeros-2014-pdf.aspx.

10. Álvaro-Meca A, Debón A, Prieto RG, Gil de Miguel A. Breast cancer mortality in Spain: has it really declined for all age groups? Public Health. 2012;126:891-5.

11. Nogueira HG, Santana P. A geografia da mortalidade em Portugal 
Continental. Cad Geogr. 1999;18:65-96.

12. Bastos J, Barros H, Lunet N. Evolução da mortalidade por cancro da mama em Portugal (1955-2002). Acta Med Port. 2007;20:139-44.

13. Direção-Geral da Saúde. Portugal: Doenças Oncológicas em números - 2015: Programa Nacional para as Doenças Oncológicas. Lisboa 2016. [accessed 2017 Mar 10]. Available from: https://www.dgs.pt/ estatisticas-de-saude/estatisticas-de-saude/publicacoes/portugaldoencas-oncologicas-em-numeros-2015-pdf.aspx.

14. Direção-Geral da Saúde. Portugal. Mortalidade por cancro da mama feminina antes dos 65 anos. PNS: National Health Plan - Indicators and Targets. 2010. [accessed 2017 Jul 15]. Available from: http://impns.dgs. pt/doencas-neoplasicas/mortalidade-por-cancro-da-mama-antes-dos65-anos.

15. Instituto Nacional de Estatística, I.P. Portugal Risco de Morrer - 2012. Lisboa; 2014. [accessed 2017 Jul 15] Available from: https://www. ine.pt/ngt_server/attachfileu.jsp?look_parentBoui=217594811\&att display=n\&att_download=y

16. Direcção-Geral da Saúde. Portugal: Doenças Oncológicas em números - 2013: Programa Nacional para as Doenças Oncológicas. Lisboa; 2013. [accessed 2016 Sep 13]. Available from: https://www.dgs.pt/ estatisticas-de-saude/estatisticas-de-saude/publicacoes/portugaldoencas-oncologicas-em-numeros-2013-pdf.aspx.

17. Instituto Nacional de Estatística IP. Portugal, Causas de morte 2013. 2015. [accessed 2017 Mar 14]. Available from: https://www.ine.pt/ngt_ server/attachfileu.jsp?look_parentBoui=230098872\&att_display=n\&att_ download=y.

18. Instituto Nacional de Estatística IP. Portugal Causas de morte 2014 2016. [accessed 2017 Mar 14]. Available from: https://www.ine.pt/ xportal/xmain?xpid=INE\&xpgid=ine_publicacoes\&PUBLICACOESpub_ boui=224786815\&PUBLICACOESmodo=2\&xlang=pt

19. Direcção Geral de Saúde. Plano Nacional de Saúde 2012-2016: 7. Indicadores e Metas em Saúde. 2012. [accessed 2017 Mar 14]. Available from: http://pns.dgs.pt/files/2012/02/99_7_Indicadores_e_ Metas em Saude 2013-01-18.pdf

20. Nunes C, Briz T, Gomes D, Dias CM. A dimensão espácio-temporal em saúde pública: da descrição clássica à análise de clustering. Rev Port Saúde Pública. 2008;26:5-14.

21. Lawson $A B$. Statistical Methods in Spatial Epidemiology. $2^{\text {nd }}$ ed. Chichester: John Wiley \& Sons; 2006.

22. Areias C, Briz T, Nunes C. Pulmonary tuberculosis space-time clustering and spatial variation in temporal trends in Portugal, 2000-2010: an updated analysis. Epidemiol Infect. 2015;143:3211-9.

23. Kulldorff M, Nagarwalla N. Spatial disease clusters: detection and inference. Stat Med. 1995;14:799-810.

24. Benach J, Yasui Y, Martínez JM, Borrell C, Pasarín MI, Daponte A. The geography of the highest mortality areas in Spain: a striking cluster in the southwestern region of the country. Occup Environ Med. 2004;61:280
1.

25. Kulldorff M, Feuer EJ, Miller BA, Freedman LS. Breast cancer clusters in the Northeast United States: a geographic analysis. Am J Epidemiol. 1997;146:161-70.

26. Hsu CE, Jacobson H, Mas FS. Evaluating the disparity of female breast cancer mortality among racial groups - a spatiotemporal analysis. Int J Health Geogr. 2004;3:4.

27. Chien LC, Yu HL, Schootman M. Efficient mapping and geographic disparities in breast cancer mortality at the county-level by race and age in the U.S. Spat Spat Epidemiol. 2013;27-37.

28. Bambhroliya AB, Burau KD, Sexton K. Spatial analysis of county-leve breast cancer mortality in Texas. J Environ Public Health. 2012;959343.

29. Fukuda Y, Umezaki M, Nakamura K, Takano T. Variations in societal characteristics of spatial disease clusters: examples of colon, lung and breast cancer in Japan. Int J Health Geogr. 2005;4:16.

30. Gangnon R. A model for space-time cluster detection using spatial clusters with flexible temporal risk patterns. Stat Med. 2010;29:2325-37.

31. Yan $P$, Clayton MK. A cluster model for space-time disease counts. Stat Med. 2006;25:867-81.

32. Katayama K, Yokoyama K, Yako-Suketomo H, Okamoto N, Tango T, Inaba Y. Breast cancer clustering in Kanagawa, Japan: a geographic analysis. Asian Pac J Cancer Prev. 2014;15:455-60.

33. Pollán M, Ramis R, Aragonés N, Pérez-Gómez B, Gómez D, Lope V et al. Municipal distribution of breast cancer mortality among women in Spain. BMC Cancer. 2007;7:78

34. Ugarte MD, Goicoa T, Etxeberria J, Militino AF, Pollán M. Age-specific spatio-temporal patterns of female breast cancer mortality in Spain (1975-2005). Ann Epidemiol. 2010;20:906-16.

35. López-Abente G, Aragonés N, Pérez-Gómez B, Pollán M, García-Pérez $\mathrm{J}$, Ramis R, et al. Time trends in municipal distribution patterns of cancer mortality in Spain. BMC Cancer. 2014;14:535

36. Ellis L, Woods LM, Estève J, Eloranta S, Coleman MP, Rachet B. Cance incidence, survival and mortality: explaining the concepts. Int J Cancer. 2014;135:1774-82.

37. Dijkstra L, Poelman H. Regional working paper 2014: a harmonised definition of cities and rural areas: the new degree of urbanisation (WP01/2014). European Commission; 2014. [accessed 2016 Dec 14]. Available from: http://ec.europa.eu/regional_policy/sources/docgener/ work/2014_01_new_urban.pdf.

38. Eurostat - European Comission. Revision of the European Standard Population. Publications Office of the European Union. Luxembourg; 2013. [accessed 2017 Jul 16]. Available from: http://ec.europa.eu/ eurostat/documents/3859598/5926869/KS-RA-13-028-EN.PDF/ e713fa79-1add-44e8-b23d-5e8fa09b3f8f.

39. Gomes I, Miranda A, Nunes C. Spatiotemporal analysis of breast cance incidence: a study in Southern Portugal between 2005 and 2012. Anticancer Res. 2018;38:1797-805. 